\title{
Effect of plastic covering and potassium fertilization source on growth and fruiting of flame seedless grapevines
}

\author{
Salem, E.H ${ }^{1 *}$, Fatma El-Zahraa M. Gouda ${ }^{2}$ and M.A.A. Abdel-Raman ${ }^{3}$ \\ ${ }^{1}$ Horticulture Department, Faculty of Agriculture \& Natural Resources, Aswan University \\ ${ }^{2}$ Pomology Department, Faculty of Agriculture, Assiut University \\ ${ }^{3}$ Horticulture Department (Pomology), Faculty of Agriculture, South Valley University, \\ Qena, Egypt
}

\begin{abstract}
Grapevine growth and fruiting are affected by covering and potassium fertilization. For two years field study, 2019 and 2020 seasons in a factorial experiment in randomized complete block design were conducted to study the effects of plastic covering and potassium fertilizer sources on Flame Seedless grapevines. Flame Seedless grown in Upper Egypt and harvested between $15^{\text {th }}$ May to $10^{\text {th }}$ June. In this time, market of table grape is suffering from over supply. Thus, prices decrease considerably in the market. On other contrary, harvesting early (before mid of May) leads to at least a 50\% increase in the total income. In this experiment outdoor grown Flame Seedless grapevines were covered with UV+IR (Ultra violet + Infra-red) type of polyethylene film (PE) after dormex application at first week of January. Phenological phases like bud-burst, flowering, veraison and ripening as well as vegetative growth, yield quality were determined. Using potassin or feldspar plus potassin significantly increased the growth, and significantly improved the vine nutritional status as well as significantly yield components and improved berry quality. Plastic covering significantly enhanced the dates of all phonological phases, especially ripening that was earlier about $17 \& 22$ days in both studied seasons compared to uncovered ones. Plastic covering has a positive effect on growth aspects, yield and fruit quality. So, it could be concluded that Flame Seedless grape cultivar gave the highest and earliest yield with good berry quality when covering with plastic film and fertilized with feldspar plus potassin as natural sources of potassium.
\end{abstract}

Key words: Plastic covering; Fertilization; Grapes; Yield; Fruit quality.

\section{Introduction}

Grape is one of the most important fruit crops for local consumption and export. The total world area of grapes reached 10.5 million ha with a total production of 89million-ton fruits (FAO, 2015). In Egypt grapes are an economically important crop

\footnotetext{
*Corresponding author: E.H. Salem,

Email: nopysalem@yahoo.com

Received: February 24, 2021;

Accepted: April 9, 2021;

Published: April 11, 2021.
}

and cultivated area was 197293 feddan that produced about 1734424 ton of fruits (MALR, 2017). It is one of the most important export horticultural crop and its export value is about $10 \%$ while the quantity is about $3 \%$ of total horticultural export crops (MALR, 2019). Flame Seedless cultivar is recognized as an important commercial and early cultivar in the Egyptian market. Hence it has a great importance either for the local or international markets which exported to 
European countries. One of goals of researcher is to increase the production of fruits to satisfy the requirements for local consumptions and export to foreign markets. The increase could be achieved by importing cultural practices such as fertilization and protected cultivation of biotic and abiotic stresses (Nijjar, 1985 and Novello and de Palma, 2008). Fertilization is an important and limiting factor for growth and productivity of grapevines. Among these nutrients, potassium is considering the second nutrient for growth of plant-potassium activates enzymes that water and nutrients transport, root growth, drought and salinity resistance, biosynthesis and translocation of sugars and regulating the opening and closing of stomata that are essential for photosynthesis and enhancing the tolerance of plants to disorders infection. Potassium nutrition status not only affects grapevine growth and development, but also plays a vital role in plant resistance of diseases (Walker et al., 1998 and Leigh, 2001). Protected cultivation, using transparent plastic covering is becoming a common practice in table grapes. It has been conducted to increase water use efficiency in grapevines by creating higher humidity and lowering transpiration as compared to open field

Table (1). Some physical and chemical properties of the experiment soil site and irrigation water used.

\begin{tabular}{|c|c|c|c|}
\hline Soil property & Value 0-30 cm & Water property & Value \\
\hline Sand $\%$ & 88.99 & SAR & 0.86 \\
\hline Silt \% & 8.40 & $\mathrm{HCO}_{3} \mathrm{meq} / \mathrm{L}$ & 0.39 \\
\hline Clay \% & 1.35 & $\mathrm{EC} \mathrm{dsm}$ & 2.73 \\
\hline Texture & Sandy & $\mathrm{pH}$ & 7.55 \\
\hline $\mathrm{EC} \mathrm{dsm}^{-1}$ & 1.77 & $\mathrm{Ca}^{++}$ & 1.77 \\
\hline $\mathrm{pH}(1: 1)$ suspension & 8.1 & $\mathrm{Mg}^{++}$ & 0.98 \\
\hline Total $\mathrm{N}$ in ppm & 10 & $\mathrm{Na}^{-}$ & 13.25 \\
\hline Available $\mathrm{K}$ in ppm & 4.58 & $\mathrm{~K}^{+}$ & 0.46 \\
\hline Available $\mathrm{P}$ in ppm & 6.00 & $\mathrm{Cl}$ & 4.22 \\
\hline Available Fe in ppm & 0.55 & $\mathrm{SO}_{4}^{-}$ & 1.21 \\
\hline Available $\mathrm{Mn}$ in ppm & 0.77 & B mg/L & 0.05 \\
\hline Available $\mathrm{Zn}$ in ppm & 0.43 & $\mathrm{Fe} \mathrm{mg/L}$ & 0.03 \\
\hline Available $\mathrm{Cu}$ in ppm & 0.36 & Nozmeq/L & 0.21 \\
\hline $\mathrm{CaCO}_{3} \%$ & 0.5 & $\mathrm{Zn} \mathrm{mg/L}$ & 0.03 \\
\hline $\mathrm{Na}(\mathrm{meq} / 100 \mathrm{~g})$ & 0.78 & & \\
\hline
\end{tabular}

conditions (Stanghellini, 2014 and Permanhaniet al., 2016). In addition, using covering materials are practically used in grape production to advance the maturity has a great importance (Uzum, 1993 and Roberto et al., 2011). Increasing air temperature enhanced the dates of all phenological phases, especially ripening (Novello and de Palma, 2008; Suvocarev et al., 2013 and Doaa, 2018). So, the aim of this study was to investigate the benefits of using different potassium sources and plastic covering on fruiting of Flame Seedless grapevines.

\section{Materials and Methods}

This experiment was carried out in 2019 and 2020 seasons on 48 uniforms of Flame Seedless grapevines that as early table grape cultivar and ripen in the last week of May under Upper Egypt conditions. The vines were 8 years old and spaced at $2 \times 3$ meters apart. They have been grown in a private vineyard located at Sohag Governorate, Upper Egypt, where the soil is sandy under drip irrigation system $(0.5 \mathrm{~m}$ between dripper). Some physical and chemical properties of experimental soil and irrigation water are shown in Table (1), according to Wilde et al. (1985). 
The Spanish Barron system was used as a trellising system. Vines were cane pruned (72 buds/vine were left, 10 canes $\times 6$ buds/cane plus of 6 spurs with 2 buds) during the last week of December in each season. After berry set crop load at all vines was adjusted to 25 clusters/vine. All vines received the standard agricultural practices that are used in the vineyard including soil fertilization, irrigation, Dormex application and pest control. Soil fertilization including the addition of $20 \mathrm{~m}^{3} / \mathrm{fed}$ farmyard manure, $200 \mathrm{~kg}$ ammonium sulphate $(20.6 \% \mathrm{~N}), 150$ $\mathrm{kg}$ calcium superphosphate $\left(15.5 \% \quad \mathrm{P}_{2} \mathrm{O}_{5}\right)$ and $100 \mathrm{~kg}$ potassium sulphate $(48 \%$ $\left.\mathrm{K}_{2} \mathrm{O}\right)$ /feddan. Farmyard manure $(0.25 \% \mathrm{~N})$ was added once at the middle of January.

The experimental design was factorial experiment in randomized complete block design in a two-factor arrangement with three replicates each one consists of two vines, then: the total experimental vines were forty eight vines. The first factor was the effect of potassium fertilizer sources as follow:

1. Application the recommended potassium dose RDK (70 g K2O/vine via potassium sulphate, control).

2. Application of $30 \mathrm{ml}$ of potassin/vine as a bio-K source.

3. Application of feldspar $\left(10 \% \quad \mathrm{~K}_{2} \mathrm{O}\right)$, $525 \mathrm{~g} / \mathrm{vine}$ as a nature source of potassium (75\% RDK).

4. Application $350 \mathrm{~g}$ feldspar (50\% RDK) plus $15 \mathrm{ml}$ potassin/vine.

5. Whereas, the second factor was covered or uncovered vines, as follow:

1 - Uncovering (control, open field).

2 - Covering with plastic film 120 micron UV+IR (ultra violet + Infra-red) type of polyethylene after dormex application during the first week of January till end of April (before two weeks of harvest)

Potassium sulphate was divided into two equal batches after berry set and one month later. In addition, feldspar contains $10 \%$ potassium was added as slow-release $\mathrm{K}$ at the first week of January, one trench $(40 \times 40 \times 40 \mathrm{~cm})$ was excavated on one side of vine, then the given amount of feldspar as a part of surface soil was mixed. Moreover, potassin containing efficient strain of soluble potassium newly Bacillus circulans which used in this study as biological activators. The strain is characterized by a good ability to infect its specific host plant and its high efficiency in potassium solubilizing.

The following parameters were measured on selected vines during the two studied seasons.

\section{Vegetative characteristics}

Sample of ten mature leaves from each treated vine $\left(7^{\text {th }}\right.$ leaf from the top of the growing shoot) were collected and used for measuring leaf area according to the equation of Montero et al. (2000):

Leaf area $\left(\mathrm{cm}^{2} /\right.$ leaf $)=0.587(\mathrm{~L} \times \mathrm{W})$

Where, $\mathrm{L}=$ Length of leaf blade. W= Width of leaf blade.

Total chlorophyll content \% was determined by using (chlorophyll meter, SPAD - 502 Konica Minolta).

\section{Chemical analysis of leaf petioles}

Represented Samples of twelve petioles of leaves/replicate were collected from leaves opposite to basal clusters (Nijjar, 1985). Petioles were dried in oven at $70^{\circ} \mathrm{Cuntil}$ a 
constant weight and grinded to determine macro-elements, $0.2 \mathrm{~g}$ of crude dried powder from each sample was wet digested using a mixture of concentrated sulphoric acid and perchloric acid, then heated until become clear solution (Peterburgski, 1968). After digestion the solution was totally transferred into $50 \mathrm{ml}$ flask using distilled water to do determinations.

The modified Micro-Kjeldahl apparatus was used to determine total nitrogen according to the method procedures in A.O.A.C. (1985). Total phosphorus was also determined using Milton Roy spectronic 120 at wave length of $725 \mathrm{~nm}$ using Stannous Chloride Reduced Molybdophosphoric Blue Colors method in sulphoric system as mentioned by Jackson (1973). Total Potassium was determined using Flame photometer model Corning 400 according to the method described by Peterburgski (1968).

\section{Dates of phenological stages}

The dates of bud-burst and flowering as well as veraison and berry ripening were determined and recorded.

\section{Yield (Kg/vine)}

After harvest (covered vines at 5 and 1 May, uncovered vines at 22 and 23May in 2019 and 2020, respectively) the yield in weight (kg) was determined by multiplying number of clusters/vine by the cluster average weight.

\section{Cluster and berry characteristics}

Sample of 9 clusters per treatment, each replicate consists of 3 clusters were harvested and transported to estimate physical and chemical characteristics of berries and clusters.

1- Cluster weight (g) and berry weight (g) were determined by an electrical sensitive balance.

2- Total soluble solids (T.S.S \%): This was estimated as a percent in juice of fresh berries, a Carl Zeiss hand refractometer was used in that respect.

3- Reducing sugars was determined as outlined in A.O.A.C. (1985).

4- Total acidity content (\%) It was estimated using titration of $5 \mathrm{ml}$ clear juice against $(0.1 \mathrm{~N}) \mathrm{NaOH}$ after the addition of a little drops of phenolepthalene indicator. Acidity was expressed as gram of tartaric acid in 100 $\mathrm{ml}$ juice. The formula used was from A.O.A.C. (1985).

5- Total anthocyanin:The anthocyanin pigments were extracted by ethanolic $\mathrm{HCl}$, a mixture of $95 \%$ ethanol and $1.5 \mathrm{M} \mathrm{HCl}$ acid (85:15 v/v). A sample of $0.5 \mathrm{~g}$ from berry skin was ground and kept overnight with about $20 \mathrm{ml}$ of the solvent. The samples were then washed by aliquots of ethanolicHCl several times until the berry skin samples were colorless. The mixture was filtrated through a centered glass funnel 6.3 and extract was transferred to $25 \mathrm{ml}$ volumetric flask and completed to volume with the acidified alcohol then measured on spectrophotometer at wave length 530 . The anthocyanin content was determined from the standard calibration curve of cyaniding-3glucosid as pointed out by Markham (1982).

Data obtained were statistically analyzed due to Analysis of Variance (ANOVA) in a 
complete randomized blocks design (Gomez and Gomez, 1984), using GenStat $11^{\text {th }}$ Edition Package. The least significant differences (LSD) were used for comparing between the means according to Waller and Duncan (1969), at level of 5\%.

\section{Results}

The results of the study are presented as following:

\section{Covering effects on phenological phases}

Data presented in Table (2) showed the effect of plastic covering on phenological phases of Flame Seedless grapevines during 2019 and 2020 seasons. It is obvious that the results took similar trend during the two studied seasons. Such data indicated that covering the vines with plastic advanced the dates of phenological stages such as budburst, flowering, verasion, ripening and harvest time compared uncovered ones. Plastic covering faster bud-burst about 15 to 20 days compared with vines under open field. In addition, covering the vines enhanced blooming about 15-16 days, then leads to early verasion phase and harvested about 17-22 days than vines grown in the open field (uncovered ones).

\section{Effect of potassium fertilization and covering on leaf area and leaf contents}

Data presented in Table (3) showed that covered vines significantly increased the leaf area and leaf total chlorophyll as well as $\mathrm{N}$ and $\mathrm{K}$ contents of leaf compared to uncovered ones. The covering induces an increase by (13.77 \& 16.00\%) and (127.49 $\& 134.39 \%)$ as well as (37.62 \& $35.00 \%)$ and $(40.12 \& 36.53 \%)$ in leaf area, total chlorophyll, nitrogen and potassium content of leaf compared to uncovered vines during the two studied seasons, respectively.

Concerning the effect of potassium, data in the same table indicated that using potassin, feldspar or feldspar plus potassin significantly increased leaf area, total chlorophyll, $\mathrm{N}$ and $\mathrm{K}$ contents of leaves compared to using the recommended potassium doses via mineral-K (potassium sulphate, control). The highest values of leaf area $(173.9 \quad \& \quad 183.8 \quad \mathrm{~cm})$ total chlorophyll (49.3 \& 49.3 SPAD), leaf N \% (1.77 \& 1.72) and $\mathrm{K} \%$ (1.95 \& 2.05\%) were recorded in vines that applied with $350 \mathrm{~g}$ feldspar plus $15 \mathrm{ml}$ potassium $\left(\mathrm{K}_{4}\right)$. The lowest values for all studied growth traits were recorded due to use $100 \%$ mineral-K potassium sulphate, $\left(\mathrm{K}_{1}\right)$. Hence, the increment percentage of leaf area $(12.70 \&$ $12.55 \%)$, total chlorophyll (8.11 \& $8.60 \%)$, leaf-N (10.62 \& 9.55\%) and leaf-K (7.73 \& $13.89 \%$ ) due to use $K_{\mathbf{3}}$ compared to $K_{\mathbf{1}}$, respectively. Considering the interaction results in same table revealed that under covering conditions the highest significantly leaf area, total chlorophyll content and leaf- $\mathrm{N}$ and $\mathrm{K}$ values were measured in the vines that fertilized with $350 \mathrm{~g}$ feldspar plus $15 \mathrm{ml}$ potassin/vine. These values were $\left(185.5 \& 197.2 \mathrm{~cm}^{2}\right)$, (68.5 \& 69.1 SPAD), (2.05 \& 1.98\%) and $(2.27 \& 2.36 \%)$ for leaf area, total chlorophyll, $\mathrm{N}$ and $\mathrm{K}$ percentage during the two studied seasons, respectively.

\section{Effects on yield and bunch weight}

Data in Table (3) indicated that covered the vines significantly increased the yield/vine and cluster weight compared to uncovered ones. Such treatment includes an increase by $(8.15 \& 7.03 \%)$ and $(7.71 \& 9.05 \%)$ for yield/vine and cluster weight compared 
uncovered vine during the two studied seasons, respectively.

Concerning the effect of potassium fertilization, it is clear from the data in Table (3) that fertilization of Flame Seedless vines with different potassium fertilizer sources significantly increased the yield/vine and bunch weight compared to use mineral form only $\left(\mathrm{K}_{\mathbf{1}}\right)$.

Using, potassin or fledspar, in singly or in combination significantly increased the yield/vine and bunch weight compared to use the RDK via mineral-K source only (check treatment, $\mathrm{K}_{1}$ ). The heaviest yield/vine $(7.25 \& 8.63 \mathrm{~kg})$ and bunch weight $(288.6 \& 344.3 \mathrm{~g})$ was recorded on the vines that fertilized by $350 \mathrm{~g}$ feldspar plus $15 \mathrm{ml}$ potassin (K3), during the two studied seasons respectively. The bunch weight values were found in the following ascending order as $\mathrm{K}_{\mathbf{1}}<\mathrm{K}_{2}<\mathrm{K}_{3}<\mathrm{K}_{4}$, respectively. Then the increment percentage of yield and bunch weight was attained $(6.30 \& 5.24 \%)$ and $(6.30 \&$ $6.43 \%)$ compared to check treatment, $\mathrm{K}_{1}$ during the two studied seasons, respectively.

Considering the interaction, results indicated that under covering condition the heaviest yield and bunch weight were recorded that vines fertilized by $50 \%$ of recommended potassium dose via feldspar plus $15 \mathrm{ml}$ potassin $\left(\mathrm{K}_{2}\right)$. The combination of covering and slow release- $\mathrm{K}$ induce an increase of yield/vine by (15.60\& 13.10) and bunch weight by (15.44 \& 16.76\%) compared to uncovered vine that fertilized by recommended potassium dose via mineral-K only (check treatment) during the two studied seasons, respectively.

\section{Effects on berry quality}

Data in Table (4) indicated that covered vines significantly improved the berry quality in significantly increased the berry weight, TSS and reducing sugar and anthocyanin contents and significantly decreased the total acidity. Covering the vines induce an increase of berry weight by (9.17\& 8.14\%), TSS (14.39\& 14.73\%) and anthocyanin contents (45.71 \& 47.12\%) compared to uncovered ones during the two studied seasons, respectively.

It is evident from the data in Table (4) that using different sources of potassium fertilizers significantly improved fruit quality in terms of increasing berry weight, T.S.S.\% and reducing sugar and anthocyanin contents and decreasing the total acidity compared to use potassium sulphate (check treatment). Using either, potassin, feldspar or feldspar plus potassin significantly improved fruit quality compared to use the recommended dose of potassium (RDK) via mineral-K source only. Treating the vines with $350 \mathrm{~g}$ feldspar plus $15 \mathrm{ml}$ potassin gave the highest values of fruit traits.

The highest berry weight $(2.40 \& 2.81 \mathrm{~g})$, TSS (14.7 \& 14.3\%) and anthocyanin contents $(0.879 \& 0.849 \mathrm{mg} / \mathrm{g})$ during the two study seasons, respectively. 
Table (2).Effects of plastic covering on the dates of phonological stages of Flame Seedless.grapevine during 2019/2020 seasons.

\begin{tabular}{ccccccc}
\hline \multirow{2}{*}{$\begin{array}{c}\text { Phonological } \\
\text { stages }\end{array}$} & Covered & Uncovered & $\begin{array}{c}\text { Difference } \\
\text { (days) }\end{array}$ & Covered & Uncovered & $\begin{array}{c}\text { Difference } \\
\text { (days) }\end{array}$ \\
\cline { 2 - 7 } & $5 / 2$ & $20 / 2$ & 15 & $3 / 2$ & $23 / 2$ & 20 \\
Bud-burst & $10 / 3$ & $25 / 3$ & 15 & $12 / 3$ & $28 / 3$ & 16 \\
Flowering & $10 / 4$ & $23 / 4$ & 13 & $4 / 10$ & $29 / 4$ & 30 \\
Veraison & $5 / 5$ & $22 / 5$ & 17 & $1 / 5$ & $23 / 5$ & 22 \\
Ripening & & & & & & 2020 \\
\hline
\end{tabular}

Table (3). Effect of plastic covering and potassium fertilization on leaf area, total chlorophyll and leaf content of N and K of Flame Seedless grapevine during 2019/2020 seasons.

\begin{tabular}{|c|c|c|c|c|c|c|c|c|c|c|c|c|}
\hline & \multicolumn{2}{|c|}{$\begin{array}{c}\text { Leaf area } \\
\qquad\left(\mathrm{cm}^{2}\right)\end{array}$} & \multicolumn{2}{|c|}{$\begin{array}{c}\text { Total } \\
\text { chlorophyll } \\
\text { SPAD } \\
\text { value }\end{array}$} & \multicolumn{2}{|c|}{ N\% } & \multicolumn{2}{|c|}{ K\% } & \multicolumn{2}{|c|}{$\begin{array}{c}\text { Yield/vine } \\
\text { (kg) }\end{array}$} & \multicolumn{2}{|c|}{$\begin{array}{c}\text { Bunch } \\
\text { weight (g) }\end{array}$} \\
\hline & 2019 & 2020 & 2019 & 2020 & 2019 & 2020 & 2019 & 2020 & 2019 & 2020 & 2019 & 2020 \\
\hline$K_{1}$ & 154.3 & 163.3 & 45.6 & 45.4 & 1.60 & 1.57 & 1.81 & 1.80 & 6.82 & 8.20 & 271.5 & 323.5 \\
\hline $\mathbf{K}_{\mathbf{2}}$ & 166.1 & 176.1 & 47.8 & 47.9 & 1.69 & 1.64 & 1.88 & 1.97 & 7.01 & 8.35 & 279.2 & 332.8 \\
\hline $\mathbf{K}_{3}$ & 168.0 & 178.3 & 47.8 & 48.0 & 1.70 & 1.65 & 1.89 & 1.99 & 7.03 & 8.40 & 280.3 & 334.0 \\
\hline $\mathbf{K}_{4}$ & 173.9 & 183.8 & 49.3 & 49.3 & 1.77 & 1.72 & 1.95 & 2.05 & 7.25 & 8.63 & 288.6 & 344.3 \\
\hline $\begin{array}{c}\text { LSD } \\
5 \%\end{array}$ & 9.18 & 9.65 & 1.80 & 2.20 & 0.05 & 0.06 & 0.07 & 0.08 & 0.34 & 0.39 & 14.68 & 17.30 \\
\hline $\mathbf{C}_{1}$ & 155.4 & 162.5 & 29.1 & 28.5 & 1.42 & 1.40 & 1.57 & 1.63 & 6.75 & 8.11 & 269.5 & 319.2 \\
\hline $\mathrm{C}_{2}$ & 176.8 & 188.5 & 66.2 & 66.8 & 1.95 & 1.89 & 2.20 & 2.28 & 7.30 & 8.68 & 290.3 & 348.1 \\
\hline F-test & $* *$ & $* *$ & $* *$ & $* *$ & $* *$ & $* *$ & $* *$ & $* *$ & $*$ & $*$ & $*$ & $*$ \\
\hline $\mathbf{C}_{1} \mathbf{K}_{1}$ & 144.3 & 151.7 & 27.7 & 27.2 & 1.36 & 1.34 & 1.50 & 1.60 & 6.54 & 7.94 & 260.3 & 308.4 \\
\hline $\mathbf{C}_{1} \mathbf{K}_{2}$ & 154.7 & 162.5 & 29.2 & 28.6 & 1.42 & 1.39 & 1.57 & 1.67 & 6.77 & 8.10 & 270.4 & 320.2 \\
\hline $\mathbf{C}_{\mathbf{1}} \mathbf{K}_{\mathbf{3}}$ & 156.2 & 165.5 & 29.3 & 28.7 & 1.43 & 1.41 & 1.57 & 1.67 & 6.76 & 8.12 & 270.2 & 319.9 \\
\hline $\mathbf{C}_{1} \mathbf{K}_{4}$ & 162.3 & 170.3 & 30.1 & 29.5 & 1.48 & 1.46 & 1.63 & 1.73 & 6.94 & 8.28 & 277.3 & 328.4 \\
\hline $\mathbf{C}_{2} \mathbf{K}_{1}$ & 164.3 & 174.8 & 63.5 & 63.9 & 1.84 & 1.79 & 2.12 & 2.20 & 7.10 & 8.46 & 282.7 & 338.9 \\
\hline $\mathbf{C}_{2} \mathbf{K}_{2}$ & 177.5 & 188.6 & 66.4 & 67.1 & 1.95 & 1.89 & 2.19 & 2.27 & 7.25 & 8.61 & 288.1 & 345.4 \\
\hline $\mathbf{C}_{2} \mathbf{K}_{3}$ & 179.8 & 191.3 & 66.4 & 67.3 & 1.96 & 1.90 & 2.20 & 2.29 & 7.30 & 8.67 & 290.3 & 348.0 \\
\hline $\mathbf{C}_{2} \mathbf{K}_{4}$ & 185.5 & 197.2 & 68.5 & 69.1 & 2.05 & 1.98 & 2.27 & 2.36 & 7.56 & 8.98 & 300.5 & 360.1 \\
\hline $\begin{array}{l}\text { LSD } \\
5 \%\end{array}$ & 12.94 & 13.61 & 2.60 & 3.10 & 0.07 & 0.10 & 0.11 & 0.12 & 0.48 & 0.55 & 20.76 & 24.9 \\
\hline
\end{tabular}

$\mathrm{K}_{1^{-}}$Application of $70 \mathrm{~g} \mathrm{~K}_{2} \mathrm{O}$ /vine via potassium sulphate (control).

$\mathrm{K}_{2}$ - Application of $30 \mathrm{ml}$ of potassin as a bio-K source.

$\mathrm{K}_{3}$ - Application of feldspar $\left(10 \% \mathrm{~K}_{2} \mathrm{O}\right), 525 \mathrm{~g} /$ vine as a nature source of potassium.

$\mathrm{K}_{4}$ - Application $350 \mathrm{~g}$ feldspar plus $15 \mathrm{ml}$ potassin/vine.

$\mathrm{C}_{1}$ - Uncovering (control, open field).

$\mathrm{C}_{2}$ - Covering with plastic film 120 micron UV+IR (ultra violet + Infra-red) type of polyethylene after dormex application during the first week of January till end of April (before two weeks of harvest) 
Table (4). Effect of plastic covering and potassium fertilization on yield and berry quality of Flame Seedless grapevines during 2019/2020 seasons.

\begin{tabular}{|c|c|c|c|c|c|c|c|c|c|c|}
\hline & \multicolumn{2}{|c|}{$\begin{array}{c}\text { Berry } \\
\text { weight }(g)\end{array}$} & \multicolumn{2}{|c|}{ TSS\% } & \multicolumn{2}{|c|}{$\begin{array}{l}\text { Reducing } \\
\text { sugar \% }\end{array}$} & \multicolumn{2}{|c|}{$\begin{array}{c}\text { Anthocyanin } \\
(\mathrm{mg} / \mathrm{g})\end{array}$} & \multicolumn{2}{|c|}{ Acidity \% } \\
\hline & 2019 & 2020 & 2019 & 2020 & 2019 & 2020 & 2019 & 2020 & 2019 & 2020 \\
\hline $\mathbf{K}_{\mathbf{1}}$ & 2.16 & 2.53 & 13.6 & 13.4 & 10.20 & 9.98 & 0.804 & 0.789 & 0.62 & 0.63 \\
\hline $\mathbf{K}_{\mathbf{2}}$ & 2.28 & 2.70 & 14.1 & 13.3 & 10.70 & 10.46 & 0.848 & 0.812 & 0.56 & 0.58 \\
\hline $\mathbf{K}_{\mathbf{3}}$ & 2.29 & 2.71 & 14.1 & 13.8 & 10.73 & 10.50 & 0.853 & 0.818 & 0.57 & 0.57 \\
\hline $\mathbf{K}_{4}$ & 2.40 & 2.81 & 14.7 & 14.3 & 11.19 & 10.95 & 0.879 & 0.849 & 0.53 & 0.54 \\
\hline $\begin{array}{l}\text { LSD } \\
5 \%\end{array}$ & 0.12 & 0.12 & 0.47 & 0.38 & 0.38 & 0.43 & 0.028 & 0.041 & 0.02 & 0.03 \\
\hline $\mathbf{C}_{1}$ & 2.18 & 2.58 & 13.2 & 12.19 & 9.96 & 9.73 & 0.687 & 0.660 & 0.71 & 0.71 \\
\hline $\mathrm{C}_{2}$ & 2.38 & 2.79 & 15.1 & 14.8 & 11.45 & 11.22 & 1.001 & 0.971 & 0.43 & 0.45 \\
\hline F-test & $*$ & $*$ & $* *$ & $* *$ & $* *$ & $* *$ & $* *$ & $* *$ & $* *$ & $* *$ \\
\hline $\mathbf{C}_{1} \mathbf{K}_{1}$ & 2.03 & 2.39 & 12.7 & 12.5 & 9.52 & 9.30 & 0.646 & 0.621 & 0.75 & 0.76 \\
\hline $\mathbf{C}_{1} \mathbf{K}_{2}$ & 2.20 & 2.61 & 13.2 & 12.8 & 9.95 & 9.71 & 0.688 & 0.661 & 0.70 & 0.71 \\
\hline $\mathbf{C}_{1} \mathbf{K}_{3}$ & 2.19 & 2.60 & 13.2 & 12.9 & 9.98 & 9.74 & 0.694 & 0.665 & 0.71 & 0.70 \\
\hline $\mathbf{C}_{1} \mathbf{K}_{4}$ & 2.29 & 2.71 & 13.6 & 13.3 & 10.41 & 10.16 & 0.721 & 0.695 & 0.67 & 0.67 \\
\hline $\mathbf{C}_{2} \mathbf{K}_{1}$ & 2.29 & 2.67 & 14.6 & 14.3 & 10.88 & 10.66 & 0.954 & 0.926 & 0.48 & 0.49 \\
\hline $\mathbf{C}_{2} \mathbf{K}_{2}$ & 2.36 & 2.78 & 15.0 & 14.7 & 11.45 & 11.22 & 1.006 & 0.972 & 0.42 & 0.45 \\
\hline $\mathbf{C}_{2} \mathbf{K}_{3}$ & 2.39 & 2.82 & 15.1 & 14.8 & 11.48 & 11.25 & 1.010 & 0.980 & 0.42 & 0.44 \\
\hline $\mathbf{C}_{2} \mathbf{K}_{4}$ & 2.48 & 2.90 & 15.7 & 15.4 & 11.97 & 11.74 & 1.035 & 1.004 & 0.40 & 0.42 \\
\hline $\begin{array}{l}\text { LSD } \\
\mathbf{5 \%}\end{array}$ & 0.17 & 0.17 & 0.67 & 0.54 & 0.54 & 0.61 & 0.040 & 0.058 & 0.03 & 0.04 \\
\hline
\end{tabular}

In addition, the interaction showed the significantly improving the berry quality in terms of increasing the berry weight, TSS, anthocyanins contents and decreasing the total acidity compared to uncovered vines which fertilized by mineral-K (check treatment). The heaviest berry weight $(2.48$ $\& 2.90 \mathrm{~g})$ and highest TSS (15.7 \& 15.4) and anthocyanin content $(1.035 \& 1.004$ $\mathrm{mg} / \mathrm{g}$ ) were recorded on vines that covered and fertilized by $350 \mathrm{~g}$ feldspar plus $15 \mathrm{ml}$ potassin. Hence such treatment induces as increase of berry weight by (22.17 \& $21.33 \%)$, TSS by (23.62 \& 23.20) and anthocyanin contents by $(60.02 \& 61.67 \%)$ compared to check treatment during the two studied seasons, respectively.

An overview of these results, it could be concluded that the combination treatments were more effective than individual application of either covering or fertilization. Such treatments are very important for the grapevines production since they improve the berry quality and advanced the maturity induce an increase in packable yield.

\section{Discussion}

Increasing water used efficiency as well as advancing the maturity early grape cultivar are the great importance for grape production. These could be achieved by improving cultural practices i.e. fertilization and protected cultivation.

Grapevines under plastic cover tend to have leaves with larger area, since the suitable conditions (light and water) led to increasing leaf area (Chavarria et al., 2008) as well as increased chlorophyll content of 
grapevines under plastic cover (Chavarria et al., 2012). The chlorophyll concentration in leaves is considered as an indicator of the photosynthetic activity of plants (Taiz and Zeiger, 2004). Higher differences found between covered and uncovered vines may be due to an easier stomatal opening under plastic covering since transpiration process is restricted under low solar radiation and wind speed (Cardoso et al., 2008; Chavarria et al., 2009).

Plastic covering of grapevines has a positive effect in enhancing all phenological phases. Due to the higher temperatures under plastic covers especially after flowering time. Also, higher temperatures during January under plastic covers cause an earlier budburst.

The above-mentioned results were consistent with Coban, 2007, Chavarria et al., 2009 and Chavarria et al., 2012 who emphasized the highly positive effect of plastic covering on the phonological stages of table grapes.

The obtained results agree with those reported by DeSouza et al. (2015), they found that the lowest grape quality was observed from uncovered vines. This treatment showed the lowest total soluble solids and the highest acidity as compared to covered vines. In the same line, Abd Elwahed et al. (2015) reported that plastic house treatment increased TSS\% and decreased acidity in berry juice of Thompson seedless grapevines.

Potassium is an important element in the formation and function of proteins, fats, carbohydrates and chlorophyll and in maintaining the balance of salts and water in plant cell (Marschner, 1995). Crop demands for $\mathrm{K}$ become great expense due to lack of natural $\mathrm{K}$ resources. Exploration of alternative sources of potassium has been taken into consideration. In addition, there are increasing interest and demand for organic, bio and slow releasing-K sources to conventional and organic forming.

The feldspar as a slow release- $K$ gave a significant advantage if the release continues over several years. The residual material after release of potassium and other nutrients easily gets soil fertility. The feldspar effects due to its role as a potassium source which it activates a lot of physiological process as occur in plant such as maintaining cell organization, cell hydration and permeability. It activates many enzymes system such that occur in protein synthesis and formation of carbohydrates (Nijjar, 1985; Tamim et al., 2000).

The importance of application of natural rocks (Rock-feldspar) may be attributed to their release of macro elements which make converting them in soluble forms of $\mathrm{P}, \mathrm{K}$, $\mathrm{Ca}$ and $\mathrm{Mg}$ in comparison with the fertilizers with potassium sulphate. Also, rock-feldspar is rich in its content of macro and micro elements which reflected on improve the photosynthesis process, this means that more sugar is available for growth and fruit quality.

The promotive effect of potassium fertilization on growth nutrient status and fruiting of grapevines were emphasized by Georgieva (1977), Morris and Cawthon (1982), Morris et al. (1983), Tisdale et al. (1985), Ahmed et al. (1989), Akl et al. (1993), Dhillon et al. (1999), Omar (2000), Arafat et al. (2000), Shoaieb (2002), Tano et al. (2005), Abdel-Salam, Mahaet al. (2009), El-Kady (2011), Belal et al. (2017), Mohyeldein et al. (2019) and Dakrony, Mona (2020). They concluded that using different forms of potassium fertilization 
had a positive effect on growth and leaf mineral content, as well as yield and berry quality different grape cultivars.

\section{Conclusion}

From the mentioned results, it could be concluded that Flame Seedless grapevine gave the highest and earliest yield with good berry quality when potassium fertilization via natural (feldspar) plus bioform (potassin) sources under covering with plastic film. Hence increasing the total income of covered farms due to high prices.

\section{References}

A.O.A.C. Association of Official Agricultural Chemists (1985) 'Official Methods of Analysis A.O.A.C' Benjamin Franklin Station, Washington, DC, M.S.A., pp. 440512.

Abd Elwahed, M.S., El-Saeed, H.M., Abou ziena, H.F. and Ali, Z.A. (2015) 'Increasing the opportunities of early grape production for exportation using some protection treatments in Egypt' Int. J. Chem. Tech. Res., 8(4):1601-1609.

Abdel-Salam, Maha, M., Ahmed-Amin, Kamelia I., and El-Salhy, A.M. (2009) 'Improvement of Flame seedless grapes quality for exportation'Assiut J. of Agric. Sci., 40 (3): 73-96.

Ahmed, F.F., Rabie, M.H., Abdel-Latif, E.A., Osama, A.O., and Assy, K.G. (1989) 'Effect of foliar application of urea and potassium sulphate on cracking, shot berries and production of Red Roomy grapevine (VitisviniferaL.)', Agric. Res. Rev. Dokki, Cairo.
Akl, A.M., Eid, A.M., Ahmed, F.F. and Abdel-Al, A.H. (1993) 'The effect of soil and foliar applications of nitrogen, phosphorus and potassium on some vegetative and fruiting characteristics in White Banaty seedless grapevine. 1-Vegetative growth and leaf nutrient content'Minia First Conf. for Hort. (19-21 Oct.) Part 2, Fruit Crops, 431 451.

Arafat, S.M., Yassen, A., and AbouSeeda M. (2000) 'Agronomic evaluation of fertilizing efficiency of vinasse' Egyptian Soil Science Society (ESS) Golden Jubilee Congress, Oct. 23-25 Cairo, Egypt: 204-205

Cardoso, L.S., Bergamaschi, H., Comiran, F., Chavarria, G., Marodin, G.A.B., Dalmago, G.A., Santos, H.P. and Mandelli, F. (2008) 'Micrometeorological alterations in vineyards by using plastic covering' Pesquisa Agropecuaria Brasileira, Brasilia, 43(4):441-447.

Chavarria, G., Santos, H.P., Felippeto, J., Marodin, G.A.B., Bergamasch, H., Cardoso, L.S. and Fialho, F.B. (2008) 'Water relations and leaf gas exchange in vineyard with plastic overhead cover' RevistaBrasileira de Fruticultura, Jaboticabal, (30):10221029.

Chavarria, G., Santos, H.P., Castro, L.A.S., Marodin, G.A.B. and Bergamaschi, H. (2012) 'Anatomy, chlorophyll content and photosynthetic potential in grapevine leaves under plastic cover' RevistaBrasileira de Fruticultura, 34(3): 661-668.

Chavarria, G., Cardoso, L.S., Bergamaschi H., Santos, H.P., Mandelli, F., and Marodin, G.A.B. (2009) 'Microclimate of vineyards under 
protected cultivation 'Ciencia Rural, 39(7): 2029-2034.

Coban, H. (2007) 'Effect of plastic covering on yield physical and chemical characteristics of some table grapes (Vitisvinifera L.)' Asian J. of Chemistry, 19 (5): 4052-4058.

Dakrony-Mona, M. (2020) 'Enhancing fruiting of Early Sweet grape cultivar under Upper Egypt climatic conditions' M.Sc. Thesis, Fac. of Agric., Assiut Univ., Egypt, 109 p..

De Souza, C.R., Da Mota, R.V., Dias, F. A. N., De Melo, E.T., Pimentel, R. M. A., De Souza, L.C and De Albuquerque, R.M. (2015) 'Physiological and agronomical responses of Syrah grapevine under protected cultivation' Bragantia, 74(3):270-278.

Dhillon, W.S., Bindra, A.S. and Bar, B.S. (1999) 'Response of grapes to potassium fertilization in relation to fruit yield, quality and petiole nutrient status', J. of Indian Society of Soil Sci., 47 (1): 89-94.

Doaa, M.H. (2018) 'Effect of Plastic Covering and Rootstocks on Yield, Physical and Chemical Characteristics of Superior Grapevines (VitisviniferaL.)' J. Plant Production, Mansoura Univ., Vol. 9 (10):839- 844.

El-Kady, A.M.A. (2011) 'Effect of certain cultural treatments on growth and productivity of some seedless grape cultivars' Ph.D. Thesis, Fac. Agric., Assiut Univ., Egypt,173p.

FAO (2015) 'Food and Agriculture Organization of the United Nations' Rome, 2015 Cited from www.fao.org/publications.
Georgieva, S. (1977) 'Determination of the fertilizer requirement of grapevines by qualitative tests'Laser.Vin. 25 (3): 22-24 C.F: Hort. Abst. 47 (10): 927.

Gomez, K.N. and Gomez, A.A. (1984) 'Statistical Procedures for Agricultural Research' John Wiley and Sons, New York, $2^{\text {nd }} e d ., 68 p$.

Jackson, M.L. (1973) 'Soil Chemical Analysis'Prentic-Hall of IndiaPrivate, New Delhi, pp: 144-197.

Leigh, R.A. (2001) 'Potassium homeostasis and membrane transport' J. Plant Nutrition and Soil Sci., 164: 193-198.

M.A.L.R. (2017) 'Ministry of Agriculture and Land Reclamation Publishes' Economic Affairs Sector.

M.A.L.R. (2019) 'Ministry of Agriculture and Land Reclamation Publishes' Economic Affairs Sector.

Markham, K.P. (1982) 'Techniques of flavonoids identification'Academic Press, London.

Marschner, H. (1995) 'Mineral nutrition of higher plants'Academic press, London, Second Ed. 889 p.

Mohyeldein, I.S., Omer, A.E.K., Basiony, S.S. and Ghoneem, G.M. (2019) 'Effect of compost and natural rocks as partial substitutes for NPK mineral fertilizers on yield and fruit quality of Flame Seedless grapevine grown in two different locations of Egypt' Spanish J. of Agricultural Research, 17 (3): e0903.

Montero, F.J., De Juan, J.A., Cuesta, A., and Brasa, A. (2000) 'Nondestructive Methods to Estimate Leaf Area in Vitisvinifera L.' Hort. Science, 35 (4) : 696:698

Morris, J.R. and Cawthon, D.L. (1982) 'Effect of irrigation, fruit load and potassium fertilization on yield quality and petiole analysis of 
concord (Vitisvinifera L.) grapes' Amer. J. Enol. Vitic., 33 (3): 145-148.

Morris, J.R., S.E. Spayd and D.L. Cawthon (1983) 'Influence of drip irrigation on "Concord" grapes’ Ark. Farm Res. 32 (3): 5 .

Nijjar, G.S. (1985) 'Nutrition of Fruit Trees' Mrs. UshaRaji Kumar Kilyani, New Delhi, India: 206-234.

Novello, V. and de Palma, L. (2008) 'Growing grapes under cover' ActaHortic., 785: 353-362.

Omar, A.H. (2000) 'Potassium application to Thompson seedless grapevines in clay soil' J. Agric. Sci. Mansoura Univ., 25 (4): 2197-2204.

Permanhani, M., Miguel, J. Costa, Conceicao, M.A.F., Rde Souza, T., Vasconcellos, M.A.S. and Chaves, M.M. (2016) 'Deficit irrigation in table grape: eco-physiological basis and potential use to save water and improve quality' Theory Exp. Plant Physiol., 28 (1): 85-108.

Peterburgski, A.V. (1968) 'Hand Book of Agronomic Chemistry' Kolas publishing House, Moscow, (in Russian), pp: 29-86.

Roberto, S.R., Colombo L.A. and de Assis, A.M. (2011) 'Review: protect cultivation in viticulture' Cienc. Tec. Vitivinic., 26:11-16.

Shoaieb, M.M. (2002) 'A comparative study on the effect of soil or foliar application of potassium to Flame vines' Proc. Minia $1^{\text {st }}$ Conf. for Agric. \& Environ. Sci., Minia, Egypt. March 25-28, 2002.

Stanghellini, C. (2014) 'Horticultural production in greenhouses: efficient use of water' Acta Hortic., 1034: 2532.

Suvočarev, K., Blanco, O., Faci, J.M. Medina, E.T. and Martınez-Cob, A. (2013) 'Transpiration of table grape (VitisviniferaL.) trained on an overhead trellis system under netting' Irrig. Sci., 31:1289-1302.

Taiz, L. and Zeiger, E. (2004) 'Fisiologia vegetal' 3ed Porto Alegre: Artmed.

Tamim, M., E.E. Golschmidt, R. Goren and A. Shachnai (2000) 'Potassium reduces the incidence of superficial rind pitting (nauxan) on "Shamouti" orange', Alon.Hanotea, 54 (4): 152157.

Tano, F., Valenti, L., Failla, O. and Beltrame, E. (2005) 'Effect of distillery vinasses on vineyard yield and quality in the D.O.C. "Oltrepopavese Pinot Naro" Lambardy, Italy' Water Science and Technology, 51 (1): 199-204.

Tisdale, S.L., Nelson, W.L. and Reaton, J.D. (1985) 'Soil fertility and fertilizer' Published by Macmillan Publishing Company, New York, U.S.A.

Uzum, H.I. (1993) 'Effects of plastic covering on early ripening some table grapes' Doga Turkish J. Agric. Forestry, 17: 111-118.

Walker, D.J., Black, C.R. and Miller, A.J. (1998) 'The role of cytosolic potassium and $\mathrm{pH}$ in the growth of barley roots' Plant Physio., 118: 957964.

Waller, R.A. and Duncan, D.B. (1969) 'A bays rule for the symmetric multiple comparison problem' J. Amer. Assoc., 64: 1484-1503. 94-105. 